KERUGMA, VOLUME 2 NUMBER 1 APRIL 2019

\title{
A CONSISTENCY AND AN INCONSISTENCY OF THE LEVITICUS TRANSLATOR
}

Philip Suciadi Chia

\author{
Southern Baptist Theological Seminary \\ Email: pchia275@students.sbts.edu
}

\begin{abstract}
This paper has a few goals. First is to discover if the Greek translator of Leviticus uses literal (consistent) and / or free (inconsistent) translation technique. Then, this paper will list and group the evidences of the consistency of the Greek translator in this book. If there are any examples that show the inconsistency to the MT or looseness of the translator, then this paper will study every example carefully and it will categorize into a group. This group will be created based on the examples that share the same pattern or the similarities.
\end{abstract}

Keywords: Septuagint, Old Testament and Translation Technique.

\section{INTRODUCTION}

This paper has a few goals. First is to discover if the Greek translator of Leviticus uses literal (consistent) and / or free (inconsistent) translation technique. Then, this paper will list and group the evidences of the consistency of the Greek translator in this book. If there are any examples that show the inconsistency to the MT or looseness of the translator, then this paper will study every example carefully and it will categorize into a group. This group will be created based on the examples that share the same pattern or the similarities.

The comparison of MT and LXX will be used as the methodology of this paper. Every verse will be analyzed and presented in comparison format until chapter five to have a basic knowledge of the patterns and the characteristics of the Greek Translator. The patterns, however, will be scrutinized in the whole book of Leviticus.
In depth and a detailed analysis of this comparison will be put on the appendices. This methodology will be employed to accomplish the goals of this paper.

\section{The Consistency of the Greek Translator}

As the following examples will show, the translator is consistent in word order, preposition and the article, lexical meaning, cognate words, grammatical and on the syntax level.

\section{The Word Order}

\begin{tabular}{|c|c|c|}
\hline $1: 5$ & 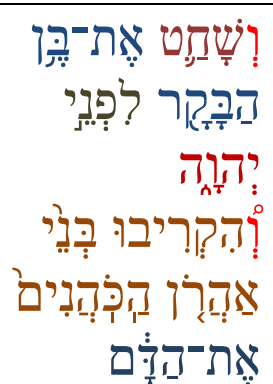 & 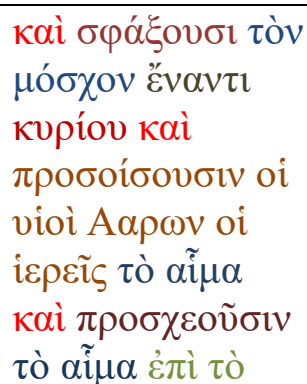 \\
\hline
\end{tabular}




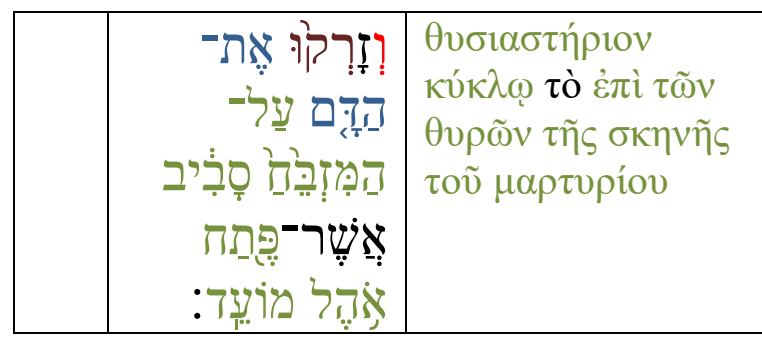

In $1: 5$, the translator follows the word order of MT perfectly. The first sentence consists of conjunctive (and), the verb and the subject (implicit), the article and the object, the preposition and the Lord. The following sentence contains: conjunctive (and), the verb and the article + the explicit subject, the article and the object. The last sentence consists of conjunctive (and), the verb and the subject (implicit), the article and object, the preposition + noun, relative pronoun, and the preposition + noun.

This "consistency" pattern of word order also appears in $1: 1 ; 1: 2 \mathrm{a} ; 1: 3 ; 1: 4 ; 1: 5$;

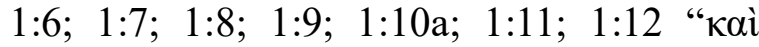

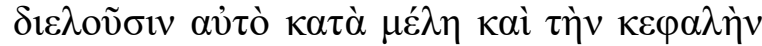

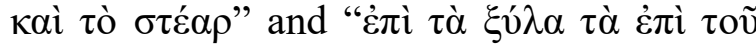

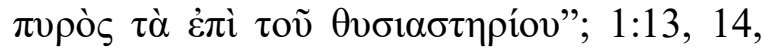
$1: 15 ; 1: 16 ; 1: 17 ; 2: 1 ; 2: 2 ; 2: 3 ; 2: 5 ; 2: 7 ; 2: 8$; $2: 9 ; 2: 10 ; 2: 11 ; 2: 12,2: 14-16 ; 3: 3 ; 3: 4,3: 6$; $3: 7 ; 3: 8,3: 9 a, 3: 10-15 ; 3: 16 ; 3: 17,4: 1-3 ; 4: 6$, 4:10, 4:11-15; 4:16-17; 4:19-35; 5:1; 5:3-9; $5: 11-15,5: 18,5: 20-22$.

\section{The Preposition and the Article}

\begin{tabular}{|c|c|c|}
\hline $3: 5$ & 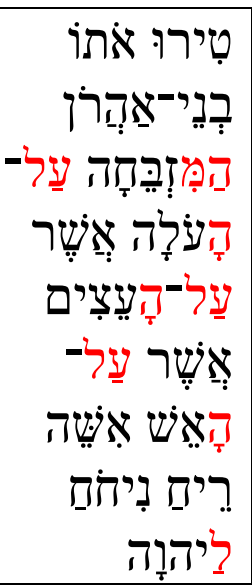 & 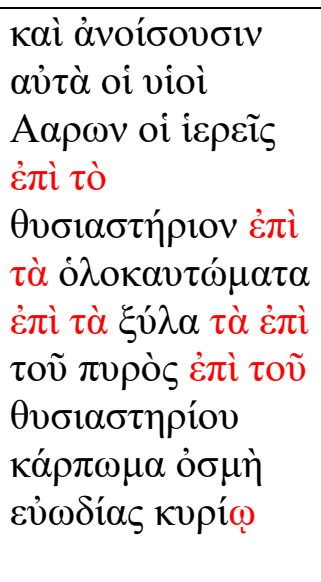 \\
\hline
\end{tabular}

In 3:5, the translator does not only follow (copy) all the prepositions and the articles, but also translate them in the literal meaning such as preposition in Greek:עֵ for غ̇ंì.

\section{The Lexical Meaning}

The Greek translator consistently translates " or cattle as owned and used by man as " $\kappa \tau \tilde{\eta} \nu \circ \varsigma^{\prime}$ " $(1: 2 ; 7: 25-25 ; 11: 3$, 26,39 , 46; 19:19, 20:16, 25; 24:18, 25:7; 26:22, 27:9-11, 26, 28). This translator also

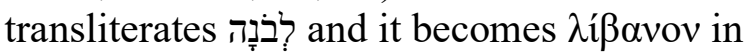
Leviticus 2:1-2.

\section{The Cognate Words}

The following examples will show that the translator has a keen eye for the cognate words.

\begin{tabular}{|c|c|c|}
\hline $2: 13$ & 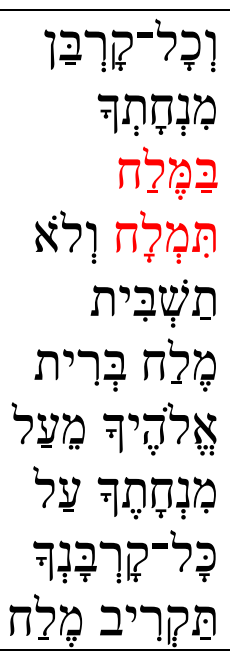 & 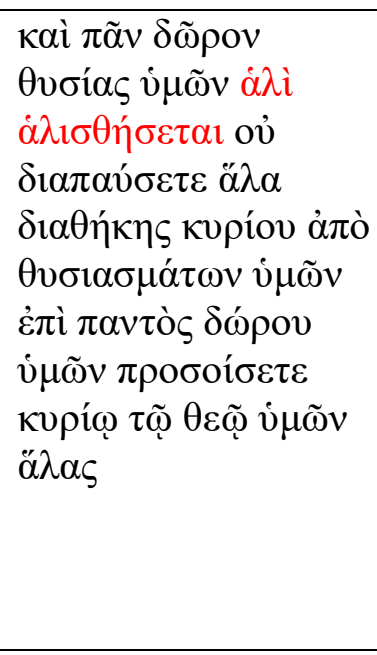 \\
\hline $5: 12$ & 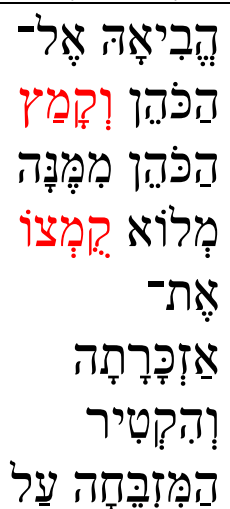 & 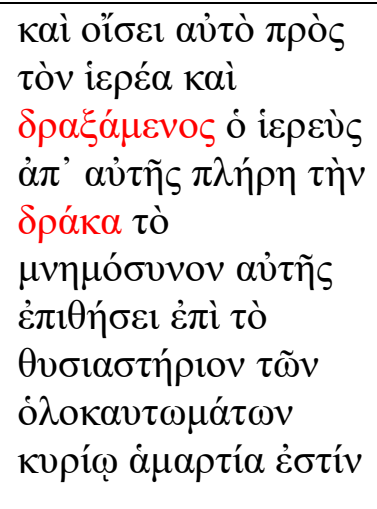 \\
\hline
\end{tabular}




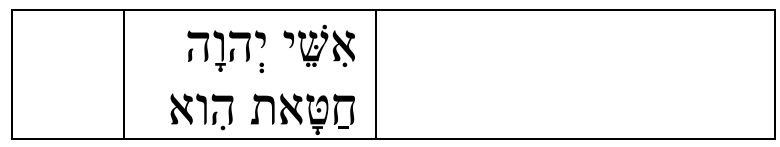

In $2: 13$, the translator maintains the cognate words of salt (מלח: in Hebrew) for both noun and verb; and he uses wordplay in his translation $\dot{\alpha} \lambda \grave{i}$ (in dative case as a substitute for a preposition $\geq$ in Hebrew) and $\dot{\alpha} \lambda \imath^{\prime} \theta \dot{\eta} \sigma \varepsilon \tau \alpha \imath$ ( $\dot{\alpha} \lambda i \zeta \omega$ is the lexical form). In $5: 12$, the translator also keeps the cognate words of grasp with hand (rap: in Hebrew)

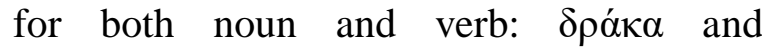
$\delta \rho \alpha \xi \alpha ́ \alpha \varepsilon v o \varsigma$.

\begin{tabular}{|c|c|c|}
\hline \multicolumn{3}{|c|}{ Grammatical Level } \\
\hline \multirow[t]{10}{*}{$2: 4$} & תַקְרְב וְדִי & 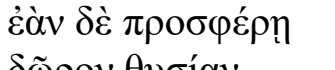 \\
\hline & 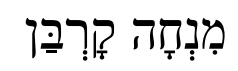 & 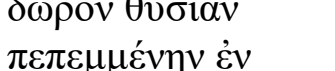 \\
\hline & תַנּוּר בַזְאַפַה & $\kappa \lambda 1 \beta \alpha ́ v \omega \delta \tilde{\omega} \rho \circ v$ \\
\hline & חַלוֹת סִדת & 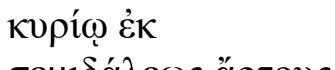 \\
\hline & 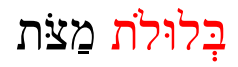 & 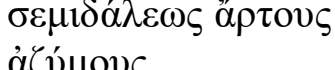 \\
\hline & 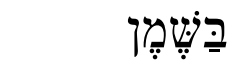 & 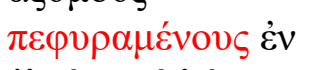 \\
\hline & 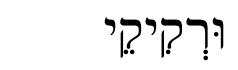 & 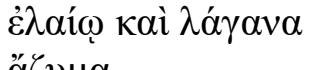 \\
\hline & מַצּוּוֹת & 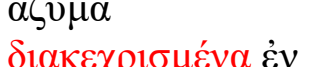 \\
\hline & 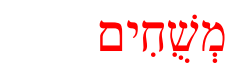 & $\dot{\varepsilon} \lambda \alpha i ́ \omega$ \\
\hline & 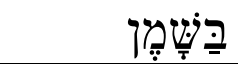 & \\
\hline \multirow[t]{6}{*}{$2: 10$} & 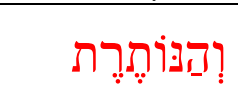 & 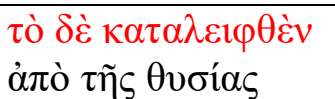 \\
\hline & 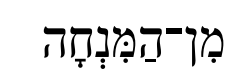 & 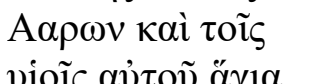 \\
\hline & 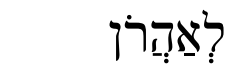 & 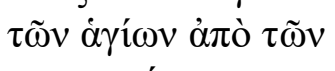 \\
\hline & 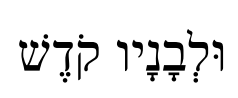 & $\begin{array}{l}\kappa \alpha \rho \pi \omega \mu \alpha ́ \tau \omega \nu \\
\kappa v \rho i ́ o v\end{array}$ \\
\hline & 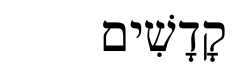 & \\
\hline & 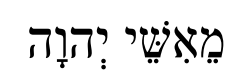 & \\
\hline
\end{tabular}

In 2:4, two Hebrew verbs are בִּלוּלוּת and מְשִֶׁחים in qal passive participle plural form.

They have been formed into two Greek participles perfect passive accusative plural:

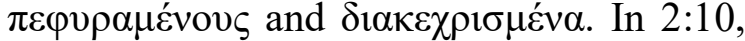
notice how precise the Greek translator is to translate every element in וְהַּוֹתֶרת It consists of ! particle conjunction; הַ article; יתר verb is niphal participle feminine singular absolute. He translates $\tau$ ò $\delta \grave{\varepsilon}$ $\kappa \alpha \tau \alpha \lambda \varepsilon i \varphi \theta \dot{\varepsilon} v$ which contains the same elements in conjunction; $\tau$ ò is the article; and a verb from participle aorist passive nominative neuter singular from $\kappa \alpha \tau \alpha \lambda \varepsilon i ́ \pi \omega$. He translates with a slight different order than the MT; LXX: article, conjunction and verb, MT, on the other hand, has conjunction, article and verb.

\section{Syntax Level}

This pattern appears also in 1:3,10,14, $3: 1[4 x], 6,7,12,4: 2,3,13,22,27,32 ; 5: 23$; $6: 11,20[2 \mathrm{x}], 23 ; 7: 12,18[2 \mathrm{x}] ; 20 ; 11: 32,33$ $[2 \mathrm{x}, 34,35,37,38,39 ; 12: 2,5,8 ; 13: 2,4,7$, $9,12,16,18,21,22,23,24,26,27,28,29$, $31,35,37,38,40,41,42,47,51,52,53,54$, 56,$57 ; 14: 21,36,43,48 ; 15: 2,4[2 \mathrm{x}], 6,8$, $10,11,13,16,17,18,19,21,22,23$ [2x], 24, $25,[2 \mathrm{x}], 26,28,31 ; 17: 16 ; 19: 5,6,7,20,33$; $20: 2,4,6,11,12,14,17 ; 21: 9,17 ; 22: 6,9$, $11,12,13,29 ; 24: 15,[2 x], 19,25: 2,14$ [2x], $20[2 x], 25,26,28,29,30,35,39,47,49,51$, 52, 54; 26:3, 14, 18, 21, 23, 27; 27:5, 7 [3x]; $8,9,10,11,13.15,16,17,18,19,20,22,26$ $[2 x], 27[2 x], 28,29,31,32,33$. The examples below are a part of clause of one verse. 


\begin{tabular}{|c|c|c|}
\hline $1: 2$ & 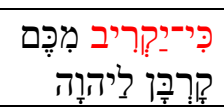 & 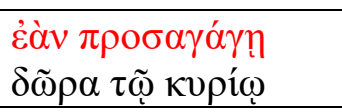 \\
\hline $2: 4$ & 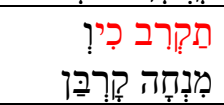 & 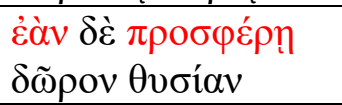 \\
\hline $4: 2$ & 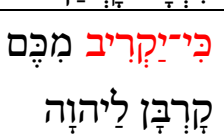 & 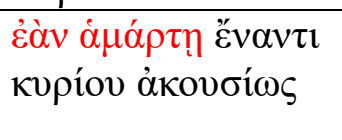 \\
\hline $5: 15$ & 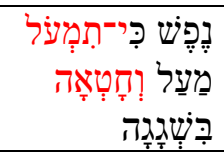 & 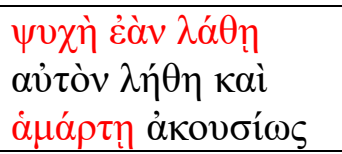 \\
\hline $5: 21$ & 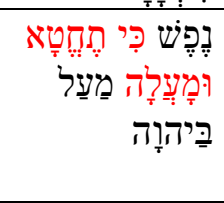 & 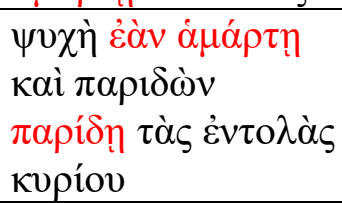 \\
\hline
\end{tabular}

The MT uses three particles (אִם ;ִִִי; (אָשֶׁר and qal imperfect to introduce the conditional clause. The Greek translator, on the other hand, uses غ̇òv plus subjunctive to match the syntax in the Hebrew text to create conditional clause; '́òv is not only a marker of condition as BDAG states, but also it is a marker of a new paragraph or idea in the book of Leviticus.

\section{The Inconsistency of the Greek Translator}

There are some reasons why the Greek translator does not follow MT: being faithful to the Greek, clarification, emphasis, Idiomatic / Stylistic Translation, homoioteleuton/ homeoarchy, smooth translation reason, avoiding repetition, and unpointed-text problem.

\section{Faithful to the Greek.}

This category has a definition that the Greek translator is consistent with the literary structure and Greek grammar while translating. The translator, therefore, has to unfollow (be unfaithful) to MT.
The Article in Greek.

This pattern appears in $1: 4,10,3: 2,8,13 ; 4: 4$, $15,24,29,33 ; 8: 9,12,14,18,22 ; 14: 18,29$, $16: 21 ; 21: 10,24: 14$.

\begin{tabular}{|c|c|c|}
\hline $16: 21$ & על ראש & 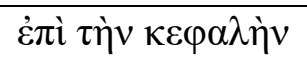 \\
\hline
\end{tabular}

In the whole book of Leviticus, MT does not have article before the head (ראש) and after the preposition on (על). The translator, however, puts an article consistently throughout the entire book.

The 'Sentence' Pattern in Sacrificial Offering.

\begin{tabular}{|c|c|c|}
\hline $1: 10$ & 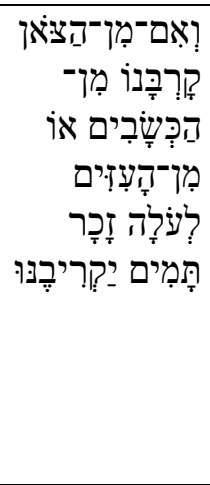 & 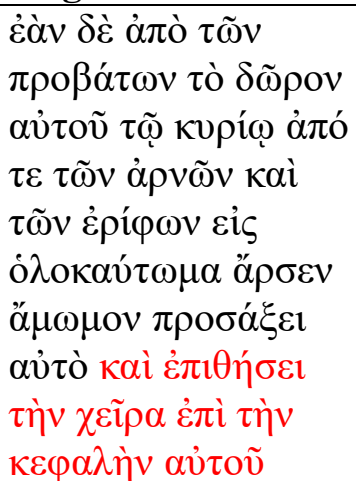 \\
\hline
\end{tabular}

Notice that MT does not have the red words in Greek. In other words, the translator adds this clause. This additional clause appears 5 times both in Hebrew and Greek in Leviticus (1:4; 4:4, 24, 29, 33). This clause is always preceded by a particular animal (1:4 is cattle; $4: 4$ is calf; $4: 24$ is a kid of goats, a male without blemish; 4:29 is a kid of goats, a female without blemish; and 4:32 is lamb, a female without blemish), and followed by a clause: they shall kill it $(1: 4 ; 4: 4,24,29,33)$. MT, however, does not maintain this pattern only in verse $1: 10$. The translator, on the other hand, keeps this pattern as we see in those verses. om this information, the Greek translator, therefore, is more consistent than MT in providing this pattern: a specific animal, laying his hand on the head and slaying the animal. 


\section{Clarification}

The previous section illustrated a few places where the translator is different from the MT because of his faithfulness to the Greek grammar and sentence pattern. This section, moreover, will illustrate places where the translator has clarified MT.

\section{The Lexical Meaning}

\begin{tabular}{|l|l|l|}
\hline $1: 5$ & זרק & $\pi \rho 0 \sigma \chi \varepsilon ́ \omega$ \\
\hline
\end{tabular}

זרק , in qal form, has a few meaning such as toss, sprinkle and throw. The translator, nevertheless, limits the definitions of word זרק; by translating as $\pi \rho \circ \sigma \chi \varepsilon \dot{\varepsilon} \omega$ : to pour on/ to (see also $1: 5,11 ; 3: 2,8,13 ; \&: 2$, 14, 8:19, 24, 9:12, 18, 17:6). For sprinkle, Greek translator uses $\pi \rho \circ \sigma \rho \alpha i v \omega$. In other word, the translator uses the word ' $\pi \rho 0 \sigma \chi \varepsilon \dot{\varepsilon} \omega$ ' to clarify and specify זרק to his Greek readers.

\section{Grammatical Level}

\begin{tabular}{|l|l|l|}
\hline $1: 2$ & 1: & $\lambda \alpha َ \lambda$ \\
\hline
\end{tabular}

The translator uses aorist imperative for piel imperative mood in Hebrew. It seems the translator employs aorist imperative to specify his discussion to burnt offering (compare Lev. 4:2). As Wallace states that the difference between aorist and present imperative is the aorist is most frequently used for a specific command rather than a general precept (usually the domain of the present).

\section{The Ending Marker of Literary Structure}

The translator adds the clause above which MT does not have. It seems that the translator adds this clause arbitrarily. The data, however, disapprove this view. This clause also appears in Leviticus 19:22 and this clause serves as an ending marker of the discussion. In addition, a clause ' $\alpha \dot{\varphi} \theta \hat{\sigma} \sigma \varepsilon \tau \alpha l$ $\alpha v ่ \tau \tilde{\omega}$ ' is always employed to close a discussion and before starting a new topic $(4: 26,31,35 ; 5: 10,13,16,18,26 ; 19: 22)$. In

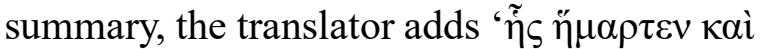

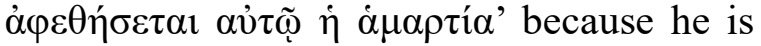
consistent with his literary structure' marker which helps his readers to be aware of a closing section.

\section{Singular translated with Plurals}

\begin{tabular}{|c|c|c|}
\hline $2: 6$ & אתָָה is using & 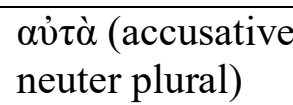 \\
\hline
\end{tabular}

MT employs singular form; the translator, on the other hand, utilizes plural form. Based on the context, the translator is being consistent to the plurality of the subject

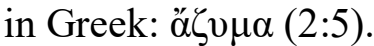

\section{Emphasis}

This section will illustrate places where the translator has a stronger nuance than MT; either put emphasis on the subject or the action.

\section{The Subject through Grammatical} Selection

\begin{tabular}{|c|c|c|}
\hline $2: 11$ & $\begin{array}{l}\text { תֶ is verb } \\
\text { niphal } \\
\text { imperfect 3rd } \\
\text { person } \\
\text { feminine } \\
\text { singular from } \\
\text { עש ע. }\end{array}$ & 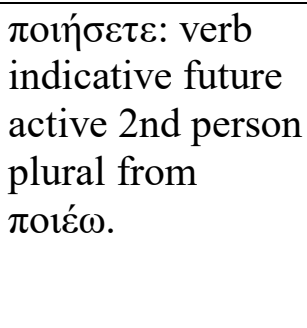 \\
\hline
\end{tabular}

There are many discrepancies from the table

\begin{tabular}{|l|l|}
\hline $5: 6$ & $\begin{array}{l}\tilde{\eta} \varsigma \\
\dot{\alpha} \mu \alpha \rho \tau i \dot{\alpha} \alpha\end{array}$ \\
\hline
\end{tabular}
observation above, except the future aspect and the lexical meaning. The translator obviously puts emphasis on the subject (the 
ones who offer), instead of the offering like what MT communicates. In summary, the translator focusses on the responsibility of the offerer through grammatical selection.

\section{The Action through Additional Verb}

\section{$4: 2,5: 17$ ở $\delta \varepsilon \tilde{\imath} \pi 01 \varepsilon \tilde{\imath} v$}

The translator adds $\delta \varepsilon \tilde{\imath}$ here to put emphasis on action about things that should have not been done as it is viewed as breaking the law of God. As BDAG states, "it is necessary of happening of the compulsion of law or custom".

\section{Idiomatic / Stylistic Translation}

The main characteristic of the Greek translator is using idiomatic and stylistic expression. This use is all over the book of Leviticus: on suffix, article, form, noun, verb, meaning (synonym) of the word, preposition / conjunction, relative particle, adverb, and independent pronoun. All information and examples will be presented in appendices. This section, however, will exhibit some of those categories and one or a few examples of each of them.

\section{On Hebrew Suffix}

The translator translates the suffix in Hebrew either with an article in Greek or personal pronouns interchangeably.

\begin{tabular}{|c|c|}
\hline Article & $\begin{array}{l}\text { Personal } \\
\text { Pronoun } \\
\end{array}$ \\
\hline 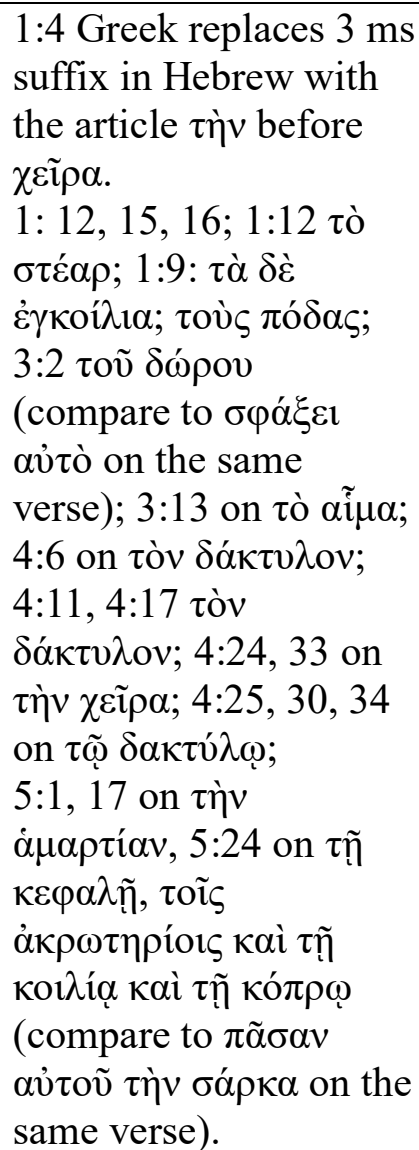 & 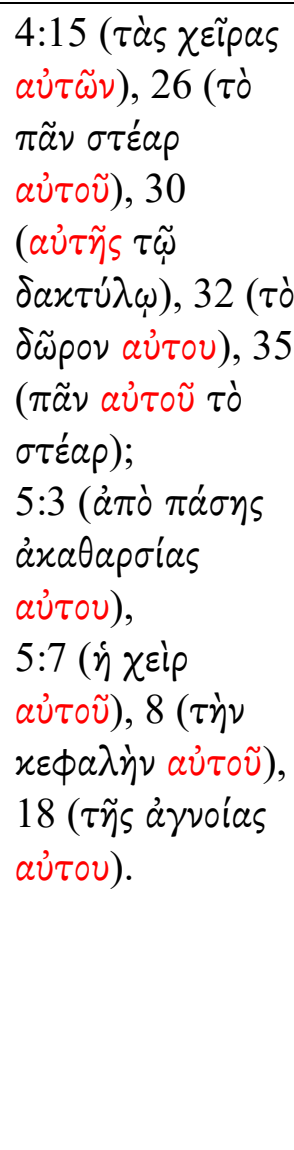 \\
\hline
\end{tabular}

\section{On Verb}

The translator tends to employ participle as a substitute of verbal form in Hebrew. Evans, in verbal syntax in the Greek Pentateuch, states that in all Pentateuchal books, there is a greater tendency for the present and perfect participles to be used in rendering Hebrew participles, other adjectives, and nouns (including Hebrew infinitives), but for the aorist participle to render Hebrew finite verbal forms. Second, Thackeray and Hanson mention, "where the participial construction is used in the Pentateuch, it is often rendered more idiomatic by varying the verb". Below are a few examples: 


\section{On Independent Pronoun}

\begin{tabular}{|c|c|c|}
\hline 1:6 & 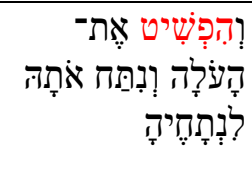 & 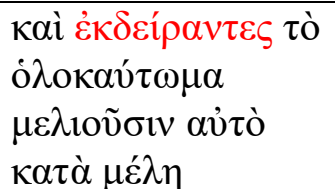 \\
\hline $2: 8$ & 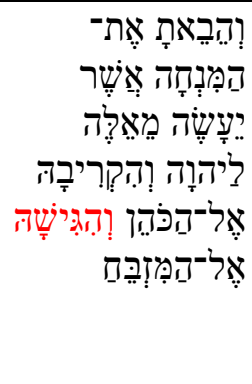 & 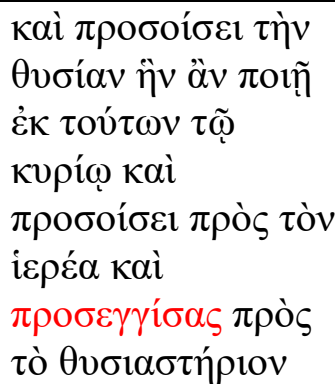 \\
\hline $4: 5 a$ & 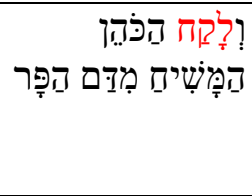 & 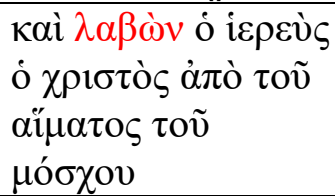 \\
\hline $5: 12$ & 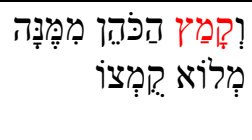 & 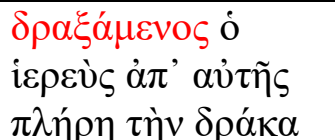 \\
\hline
\end{tabular}

This observation denotes that the Greek participle has an idiomatic function to Hebrew finite verbal forms.

\section{On Relative Particle (אֶ:שֶ)}

The translator employs the article in Greek and relative pronoun interchangeably to translate this relative particle.

\begin{tabular}{|c|c|}
\hline & Pe \\
\hline 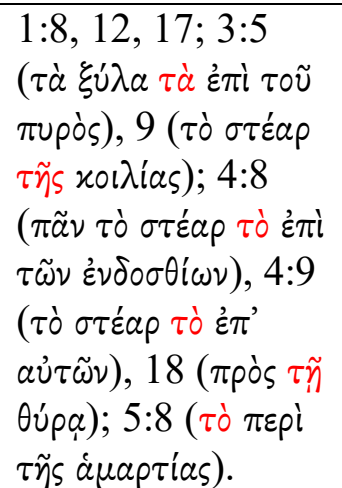 & 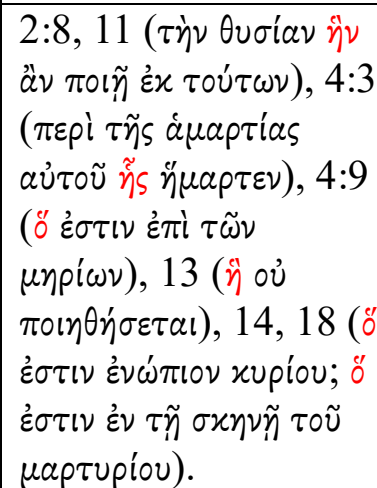 \\
\hline
\end{tabular}

The last example of idiomatic or stylistic pattern is on independent pronoun. Table below is the places in which the translator leaves independent pronoun untranslated.

\begin{tabular}{|c|c|c|}
\hline $3: 1$ & 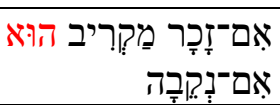 & 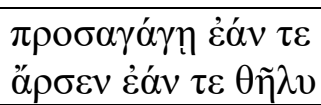 \\
\hline $5: 3$ & 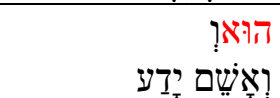 & 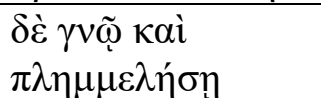 \\
\hline
\end{tabular}

The next table is the places where he translates an independent pronoun as demonstrative pronoun or personal pronoun or $\dot{\varepsilon} \sigma \tau \imath \mathrm{v}$.

\begin{tabular}{|c|c|c|}
\hline $5: 1$ & עַד הוּאוּן & 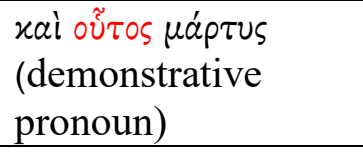 \\
\hline $5: 18$ & 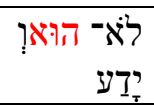 & 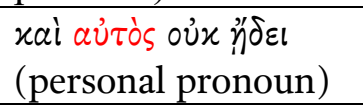 \\
\hline $11: 20$ & 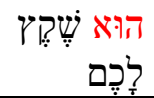 & 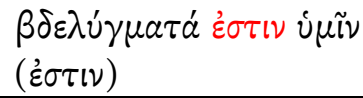 \\
\hline
\end{tabular}

Based on this observation, the translator leaves this independent pronoun untranslated for a few times $(3: 1,7,5: 2,3)$. Sometimes, he translates it as demonstrative pronoun (5:1) and personal pronoun (5:18) and uses $\dot{\varepsilon} \sigma \tau \imath \mathrm{v}$ for the rest. It brings to the conclusion that he handles this independent pronoun in HT in various ways.

\section{Homoioteleuton / Homeoarchy}

Homoioteleuton means the "same ending". Homoioteleuton occurs when two words / phrases / lines end the same sequences of letters. The scribe, having finished copying the first, skips to the second, omitting al intervening words. Homeoarchy refers to eye-skip when the beginnings of two lines are similar. 


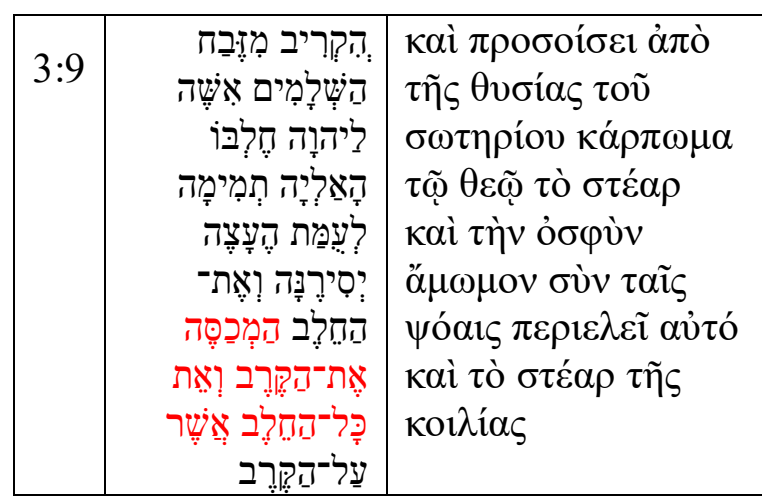

In 3:9, the translator probably misses that line / phrase since there are two clause that contains the words of fat and entrails. There are two arguments to support this theory. First is the characteristic of Greek translator; he always translates the Hebrew words, either being consistent or his work is being idiomatic / stylistic translation, and adds more words to clarify MT. He never leaves a clause or even a phrase being untranslated. The last argument is the comparison of this verse with verse $3: 3,14$ and 4:8; because the translator translates both clauses that contains the words of fat and entrails in those three verses. Leviticus 3:9 is the only occurrence that the translator only translates one clause and leaves the other clause.

\section{Smooth Translation}

The other characteristic of the Greek translator is a proneness to smoothen his translation through preposition and the usage of adverb.

\section{Preposition}

There are a few more examples in the appendices.

\begin{tabular}{|c|c|c|}
\hline $5: 16$ & 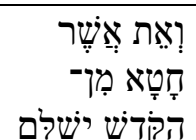 & 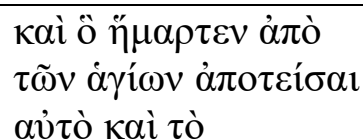 \\
\hline
\end{tabular}

\begin{tabular}{|c|c|}
\hline 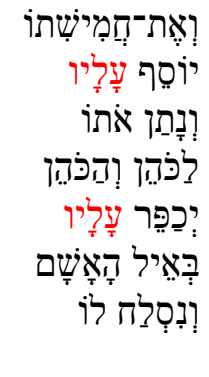 & 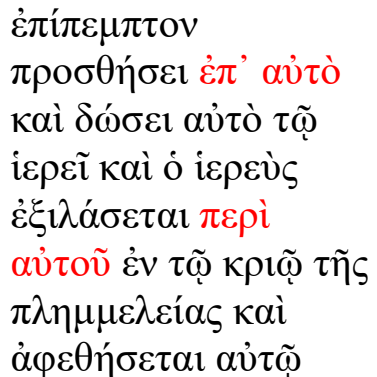 \\
\hline
\end{tabular}

In 5:16, there are two שָלָיו in MT. The translator, nevertheless, translates in two

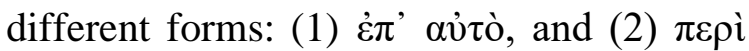

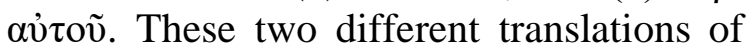
preposition tells us that the translator does not employ a rigid translation, but he smoothens it according to the Greek grammar.

\section{Adverb}

\begin{tabular}{|c|c|c|}
\hline $5: 22$ & 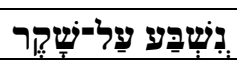 & 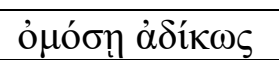 \\
\hline $5: 24$ & 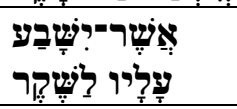 & 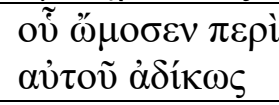 \\
\hline
\end{tabular}

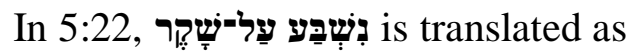
he swore on (the basis of) deception (literal translation). Instead of employing a preposition for preposition, the translator uses adverb to smoothen his translation: if he swore unjustly. This phenomenon also

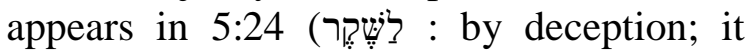
consists of ? preposition; 3 article; ms absolute). The translation of MT will be, "which he swore on (about) it with the deception". In order to produce a smooth translation, the translator ignores the preposition and the article in Hebrew and uses the adverb. The Greek translates, "which he swore concerning it unjustly". 


\section{Questionable Examples of Clarification}

There are some of questionable examples of the Greek translator such as the words that has not been translated.

\section{The Word}

\begin{tabular}{|c|c|c|}
\hline $1: 14$ & 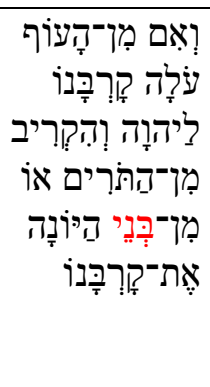 & 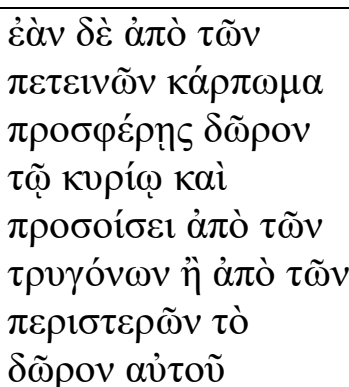 \\
\hline
\end{tabular}

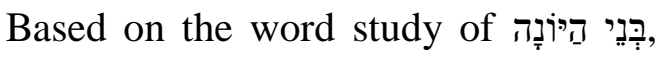
this is the only verse in which the translator

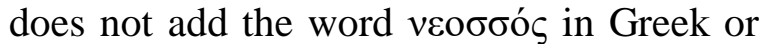
young (compare to $5: 7,11 ; 12: 6,8 ; 14: 22,30$; 15:14, 29). It could be just an idiomatic / stylistic expression. Nonetheless, the fact that this is the only verse with stylistic expression, it makes this view questionable.

\begin{tabular}{|c|c|c|}
\hline $3: 11$ & 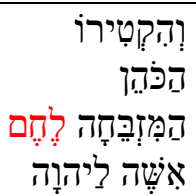 & 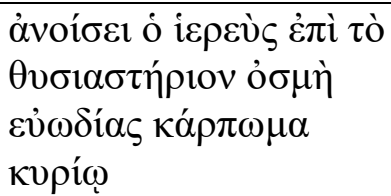 \\
\hline $3: 16$ & 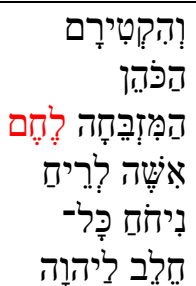 & 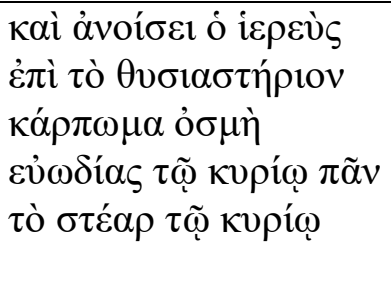 \\
\hline
\end{tabular}

In those two verses, the translator does not translate לֶ? The word study of shows that the translator translates לֶ? $\delta \tilde{\omega} \rho \alpha$ or gifts in Leviticus 7:13;21:6, 8, 17, 21,$22 ; 22: 25$; the rests are öptoc: bread / loaf. Further study is needed to examine the usage of לִ in the book of Leviticus and why the translator leaves לִ untranslated in 3:11 and $3: 16$.

\section{Conclusion}

In light of the examples collected in this paper, one cannot immediately assume that the translator is always consistent or inconsistent to MT. This paper shows that the translator is both consistent and inconsistent with MT. Nonetheless, someone cannot see the inconsistencies of translation as an arbitrary work. In addition, Dines states that these alterations are intended, apparently, to improve the Greek style. For other reasons for inconsistency, Wevers and Taylor state that the translator loves to translate a recurring Hebrew collocation in various ways, while remaining close to the original; he creates new idioms while necessary, especially when finding Greek equivalents for the technical cultic terms in which the book abounds.

\section{BIBLIOGRAPHY}

[1] $\begin{array}{ccc}\text { Dines, Jennifer } & \mathrm{M} \\ \text { The Septuagint. London: T. \& T. Clark, }\end{array}$ 2004.

[2] Evans, T. V. Verbal Syntax in the Greek Pentateuch: Natural Greek Usage and Hebrew Interference $1^{\text {st }}$ Edition. Oxford: Oxford University Press, 2001.

[3] Köhler, Ludwig, and Walter Baumgartner. The Hebrew and Aramaic lexicon of the Old Testament. 3 vols. [1st English ed.]. Leiden; New York: E.J. Brill, 1994.

[4] Liddell, H. G., R. Scott, and H. Jones. A Greek-English Lexicon. 9th ed. Oxford: Clarendon Press, 1996.

.[5] Taylor, Bernard A. (ed.) (1997) IX Congress Volume of the IOSCS, 1995. Chico CA: Scholars Press. 
KERUGMA, VOLUME 2 NUMBER 1 APRIL 2019

[6] Thackeray, H. St. J. and K.C Hanson. A Grammar of the Old Testament in Greek: According to the Septuagint. USA: Wipf and Stock Publishers, 2008.

[7] Wallace, Daniel. Greek Grammar Beyond the Basics. Grand Rapids, Michigan: Zondervan. 1997.

[8] Wevers, J. W. (1991) 'The Göttingen Pentateuch: Some Post-Partem [sic] Reflections', in Cox 1991. 